\title{
WestVirginiaUniversity
}

THE RESEARCH REPOSITORY @ WVU

West Virginia Agricultural and Forestry Experiment

Davis College of Agriculture, Natural Resources

Station Bulletins

And Design

$1-1-1894$

\section{Potatoes : potato blight, potato scab}

F.Wm. Rane

Follow this and additional works at: https://researchrepository.wvu.edu/ wv_agricultural_and_forestry_experiment_station_bulletins

\section{Digital Commons Citation}

Rane, F. Wm., "Potatoes : potato blight, potato scab" (1894). West Virginia Agricultural and Forestry Experiment Station Bulletins. 38. https://researchrepository.wvu.edu/wv_agricultural_and_forestry_experiment_station_bulletins/38

This Bulletin is brought to you for free and open access by the Davis College of Agriculture, Natural Resources And Design at The Research Repository @ WVU. It has been accepted for inclusion in West Virginia Agricultural and Forestry Experiment Station Bulletins by an authorized administrator of The Research Repository @ WVU. For more information, please contact ian.harmon@mail.wvu.edu. 



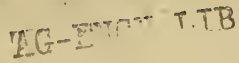

Trithraxy

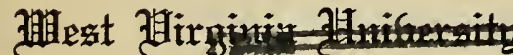

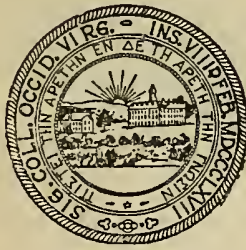

2hest tart EASDALE LIBR WES VIRGI IIIIVERSTD 


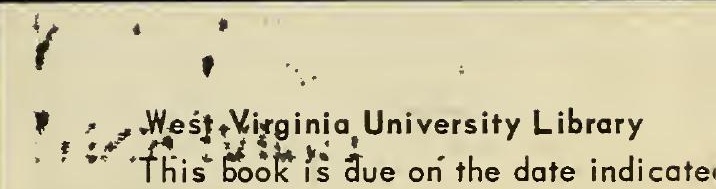
below.

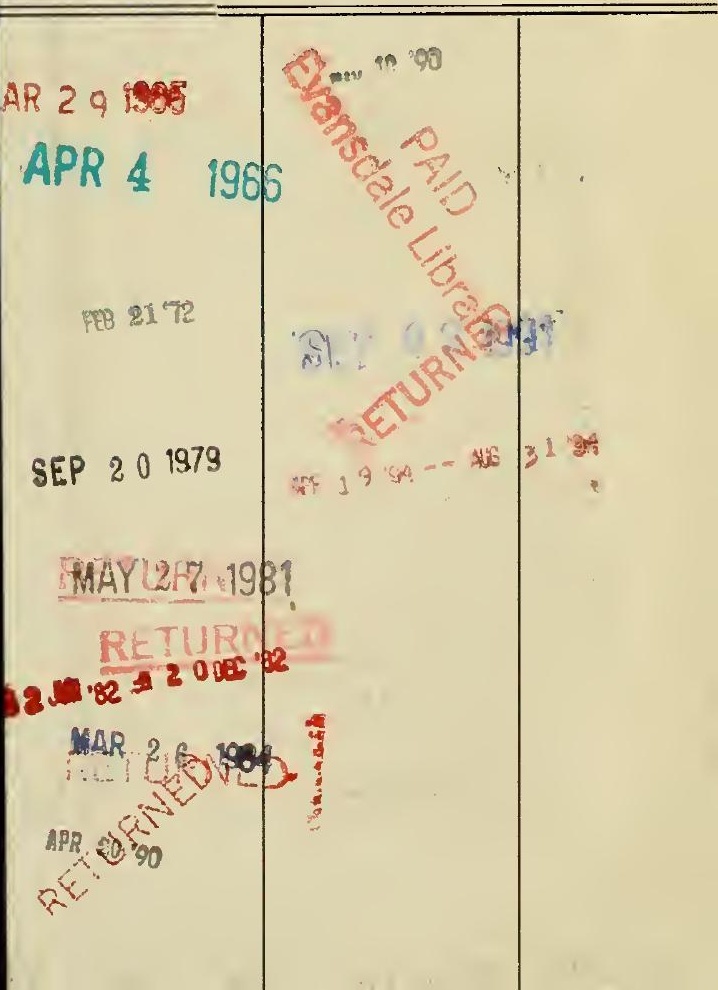



YoLUnE 11 .

Numblik 3.

\section{BULLETIN 38.}

West Virginia Agricultural Experiment Station, MORGAITOHN, W. VA.

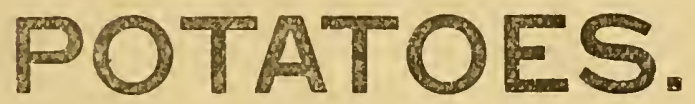

POTATO BLIGHT, POTATO SCAB.

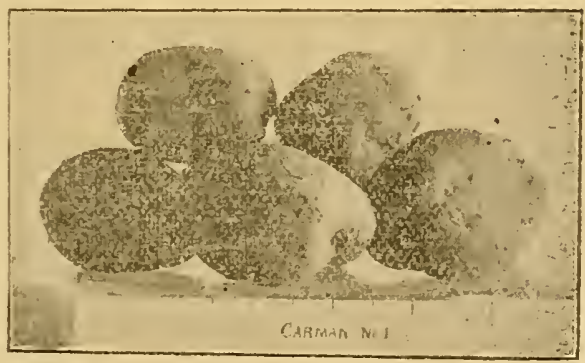

BY] F. WM. RANE.

NOVEMBER, 1894.

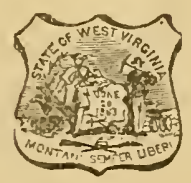

CHARLESTON :

hoags IV. Donnally, Public Printze 1894 


\section{BOARD OF REGENTS OF THE WEST VIRGINIA}

\section{UNIVERSITY.}

Distriet.

1.

2.

3.

4.

5.

6.

7.

8.

9.

10.

11.

12

13.
Name of Regent.

J. B. SUMMERVILLE,

CLARENCE L. SMITH,

J. S. WITHERS,

JOHN BASSEL,

J. M. HOLSWADE,

JAMES H. STEWART,

WIRT A. FRENCH,

M. J. KESTER,

J. F. BROWN,

THOS. J. FARNSWORTH, JOSEPH MORELAND, JOHN A. ROBINSON,

DR. W. W. BROWN,
P. O. Address.

Wheeling, W. $\mathrm{Va}$.

Fairmont, W. Va.

Glenville, W. Va.

Clarksburg, W. Va.

Spencer, W. Va.

Raymond City, W. Va.

Princeton, W. Va.

Union, W. Va.

Charleston, W. Va.

Buckhannon, W. Va.

Morgantown, W. Va.

Patterson's Depot, W.Va.

Kahletown, W. Va.

\section{MEMBERS OF THE STATION COMMITTEE.}

JOHN A. ROBINSON,

J. S. WITHERS,
C. I. SHITH, JAS. H. STEWART,

DR. W. W. BROWN.
Prest. of Board of Regents,

Acting President of the University,

P. B. REYNOLDS, LL. D.,
JOHN A. ROBINSON.

Treasurer,

A. R. WhiteHILL, Pн. D.

\section{STATION STAFF.}

JOHN A. MYERS, Ph. D.

F. Wr. RANE, M, S.

A. D. HOPKINS, Ph. D.

RUDOLF DE ROODE, Рн, D., W. E. RUMSEY, B. B. AGr.
Director.

- Horticulturist and Microscopist. - Entomologist.

Clucmist. Assistant Entomologist. 


\section{HORTICULTURAL DEPARTMENT. BULLETIN No. 38-POTATOES.}

\section{CONTENTS.}

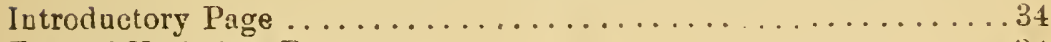

Test of Varieties, Page........................

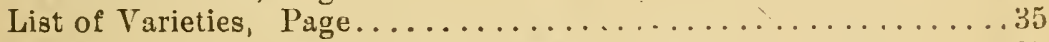

Cut showing Characteristic Variety Form 3 , Page............. . 35

Bordeanx Mixture, how made, Pago..................... 36

Paris green for potato beetle, Page.................... 36

Bordeaux and Paris grcen combined, Y'age..............37

Tables of comparisons of varieties, Page............ 38 and 39

Varieties recommended, Page....................... 40

The Leaf Blight of the potato, Page................

Treatment of Leaf Blight, Page... .. . . . . . . . . . . . .41

Flea beetle and remedy, Page...................... 42

Spraying pumps, Page...................... 42

List of Manufacturers of Spraying Pumps, Page ............43

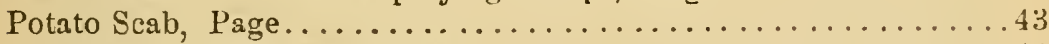

Treatment of potato scab, Page................... 44

Scab experiments, Yage....................... 46

Reports from practical potato growers, Page.............. 48

C. P. Waugh's report, Page....................... 48

Jno. D. Sanders' report, Page.................... 51 .

Donations to Horticultural Department, Page.............51

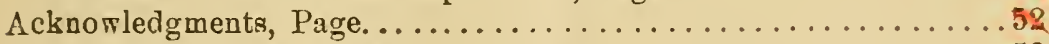

Summary Remarks, Page....................... 62 


\section{POTATOES.}

\section{POTATO BLIGHT, POTATO SCAB.}

F. WM. RANE, M. S.

The potato is an important crop in West Virginia, and in the interests of potato growers this bulletin is issued. The experiments carried on at the Station with this crop during the past year were not as extensive as we desired to make them, on account of scarcity of land, but we trust they will be of interest to the average reader.

\section{Testing of Varieties.}

For this experiment, we procured those varieties in regard to which we especially desired to know more; they numbered thirty in all. A few were duplicate varieties from different sources, but the greater number were new introductious of the past year from many of our most reliable seedsmen througbout the country. In testing these varieties we feel that we are aiding our farmers and gardeners by bringing before them the behavior of these new varieties as compared with some of the standarcl varieties already known to them. A number of these new potatoes are too expensive for the farmer or gardener to procure and grow as a general crop. In fact it often happens that only a single potato or pound of same can be secured even by us.

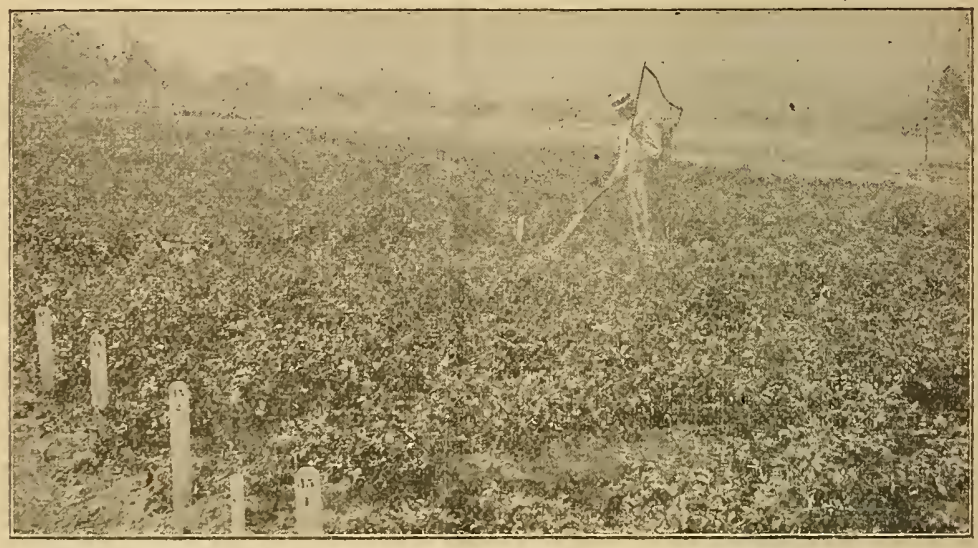

Cut 2-Variety Test Fielu.

Realizing that our people in West Virginia desire to know something about these new varieties in order that they may reap the benefits from them as early as possible, the Horticultural Department of the Station has undertaken this variety test. 
The accompanying photograph, Cut 3, page 35, together with the cut of the Carman No. 1, front page, will give a fair idea as to the characteristic form and appearance of each of the thirts-six varieties under test during the past season. The number on the putato refels to the same number before its name. The metlod pursued in selecting the specimen tu represent each variety was as follows: A certain number of potatoes of each variety was taken, from which the one containing the most decidedly typical characteristics of that variety was selected.

We are confident it will be of interest to potato.growers to see this photograph of varieties even should he not read the whole bulletin. The idfa of thus grouping the varieties to show their characteristics is new an l, ws haleve, origin 1 with us.

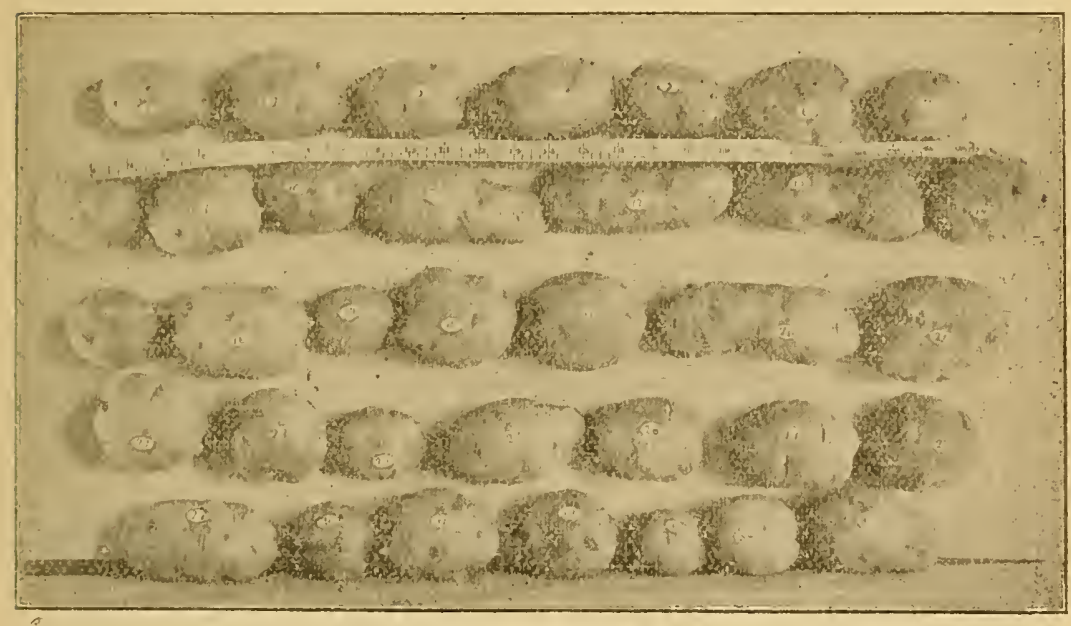

1 Harly (thon.

('ut 3 - basteristic Specimens of Each Variezy.

2. Woriy linse.

3. Warly Wveritt

4. White siar.

5. Karly Nortber.

(i. Rural New Yorker No. 2.

7. Early Six W'eeks.

8. Montana Wonder.

9. Karly Minnesola.

10. Mauiíoba Rose.

11. Great Divide.

12. Exira Farly.

13. Superior.

14. Penn Manor.

15. Bliss Triumph.

16. Crown Jewel.

17. Freeman.

18. Farmer's Alliance.
19. Standard.

20. American Wonder.

21. Maggie Murphy.

22. Badger Belle.

23. Early Pinkeye.

24. Seedling No. 99.

25. Earliest and Best.

26. Variegated.

27. Minister.

28. No Name, (Lg. Blue)

29. Stanley.

30. Early Everitt.

31. Green Mountain

32. Everitt's Heavy Weight.

33. Kveritt's Six Weeks Market.

34. Rural New Yorker No. 2.

35. Everitt's Colossal.

36. Carman No.1, (cut, front page. 
The soil was a rich clay loam and for the two previous years was not in use, but had been well fertilized preparatory for use as a lawn. It was plowed in the winter and again plowed and put in excellent condition in the spring. The planting was done April 20 and 21 for all the numbers up to and including 29 ; the remainder were planted April 28 th on account of delay in obtaining them.

The rows were euch 75 feet long and in every instance possible two rows of each variety were planted, each in a different part of the field. The average of the two rows of ths same variety constitutes, therefore, the final result. All of the seed excepting Nos. 8, 9, 10, 15, 16 and 17, came in the ordinary bulk form. The iatter came as single eye cuttings put up in gypsum or land plaster, 100 eyes in a box. In order to have the conditions similar in every instance, we made single eye cuttings of all the varieties. They were placed about six inches apart in the row.

After the plants were well up, they were sprayed both with Paris green and the Bordeaux mixture, the former to kill the common Colorado potato beetle (Doryphora decemlineata) and the latter to prevent the leaf blights. There are two well known blights that infect the potato, viz: the common leaf blight, (Macrosporium solani) and the seldom met with blight or rot (Phytophthora infestans). The former is very common in this State, but it is doubtful whether the latter can be found.

Instead of nsing the Paris green and Bordeaux mixture separately, we combine the two for the first application. It is supposed that every one understands this method, but for the benefit of those who may not, we will give the details as follows: In the first place if any one should be bothered with the common potato beetles, the remedy is to spray the vines with one-quarter pound Paris green in fifty gallons of water, or in the more common way of measuring, one tea-spoonful of Paris green to a pail of water. This will kill the bugs (beetles). Secondly, should any one be troubled with potato blight it may be remedied by spraying with the Bordeaux mixture.* (Let me say here that the common blight is extremely prevalent throughout the State; and many people who think their potatoes die on account of drouth are mistaken, for in many instances if sprayed, they continue growing in epits of dry weather).

About three applications, from two to three weeks apart, will keep it in check, the number of applications depending, however, on the season; if the weather is rainy and it washes off, more will be needed. The blight will be referred to again later on in the bulletin.

Finally, to apply them both together, we simply make up the Bordeaux mixture, and mix it with the Paris green in the same

*The Rordeaux mixture is made by dissolving five pounds of copper sulphate in hot water, to which a solution of lime is added, made by using five pounds of fresh unslacked lime and eslough water to mix it into a thin whitewash solution. Alter these have been thoroughly mixed, strdin them through an oid enfee sack or strainer into a barrel. This is done to keep out the small undissolved particles of foreign matter that might get into the pump or spraying nozzle and stop it up. Then fill the harrel with water and thoroughly nix agnin. Now it is ready for use. If applied to the vines by means of a spraying pump or dipped out and sprayed on with a common hand sprinkler it is especially necessury in either instauce to stir the whule solution occasionally to keep it from settling. 
proportion as if it were water. If, for instance, a large patch is to be gone over, we put one-quarter of a pound of Paris green into the barrel of Bordeaux, using the mixture until it is all gone. On the other hand, should we have only a small patch to go over, we add to each pail of the Bordeaux about a teaspoonful of the Paris green, mixing it as we use it. After the first application of the combined mixtures (which is called insecto-fungicide, we spray with the Bordeaux only for the blight, unless the beetles again begin to be troublesome, when we add the Paris green. The Paris green, therefore, is used only when the beetles are present.

The varieties uniler test were all treated alike and as described above, in order to give all the sume chances and to afford each an opportunity to do its best.

The culture resorted to was frequent cultivating and keeping the soil well stirred. Having thus taken every precaution, as for example, in regard to fertilizers, characteristic seed, method of planting, spraying for insects and fungous diseases, cultivation, etc., we feel that from a mechanical standpoint the results are as good as we have the power of making them. Of course such conditions as hot suns and dry weather are to a certain degree still beyond man's control. The past eeason has been an exceptionally dry one and the yield doubtless was materially affected, but as all the varieties were under the same conditions throughout, we feel safe in giving the following table showing their comparative yields, etc. : 


\begin{tabular}{|c|c|c|}
\hline & $\underbrace{2}_{2}$ & 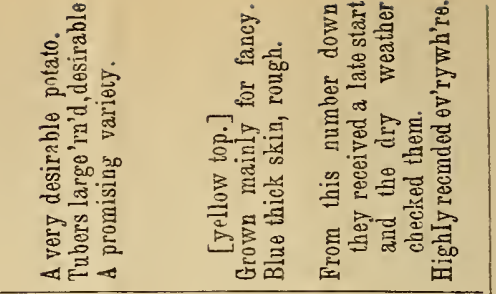 \\
\hline & 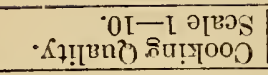 & \\
\hline & . ${ }^{2} \mathrm{IO}_{4}$ & ${ }^{\circ} \cdot 0 \mathrm{~N} 7 \mathrm{n} O \mathrm{OC}$ \\
\hline \multirow{3}{*}{$\frac{\ddot{\circ}}{8}$} & • प!MS & 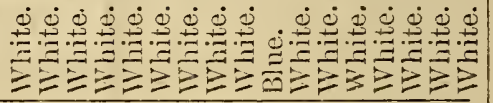 \\
\hline & •ЈәМО[Н & 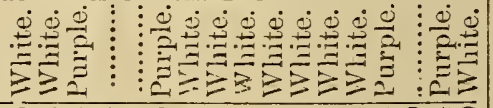 \\
\hline & 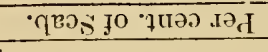 & 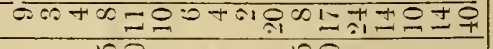 \\
\hline \multirow{4}{*}{ 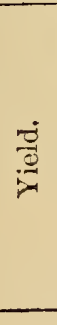 } & 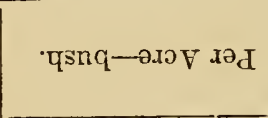 & 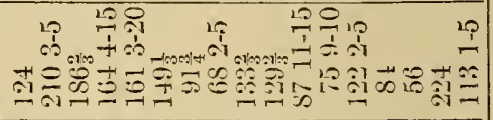 \\
\hline & -sqI-IPי7OL & 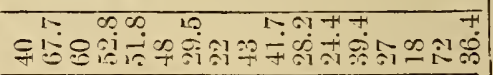 \\
\hline & -sq[-I!ßus & 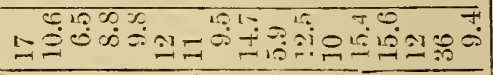 \\
\hline & 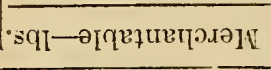 & 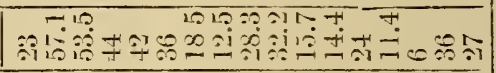 \\
\hline & .0[-0 ajmos-74. & 10061-100-7610001000 \\
\hline \multirow{2}{*}{\multicolumn{2}{|c|}{ 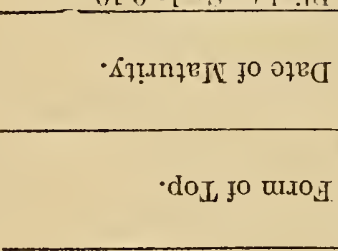 }} & 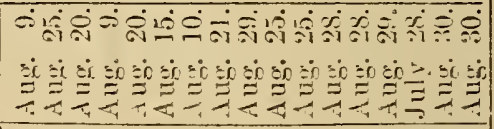 \\
\hline & & 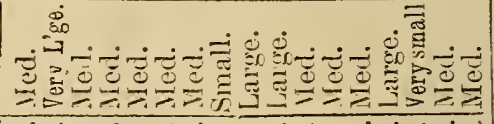 \\
\hline & 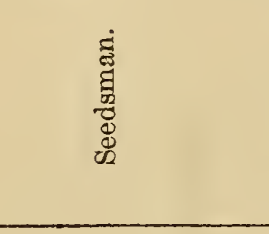 & 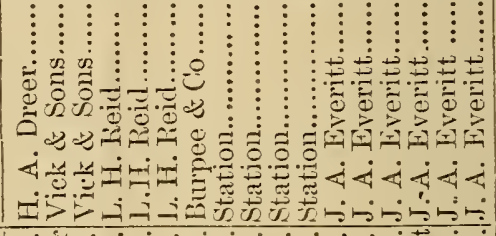 \\
\hline & $\stackrel{\overrightarrow{0}}{\vec{a}}$ & 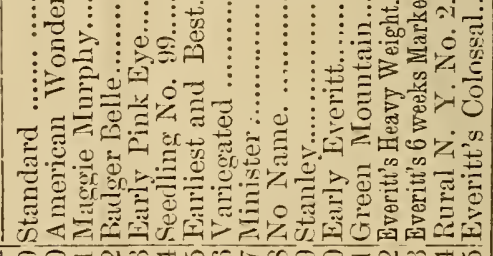 \\
\hline & $.0 \mathrm{~N}$ & 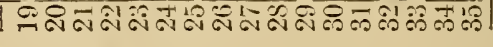 \\
\hline
\end{tabular}




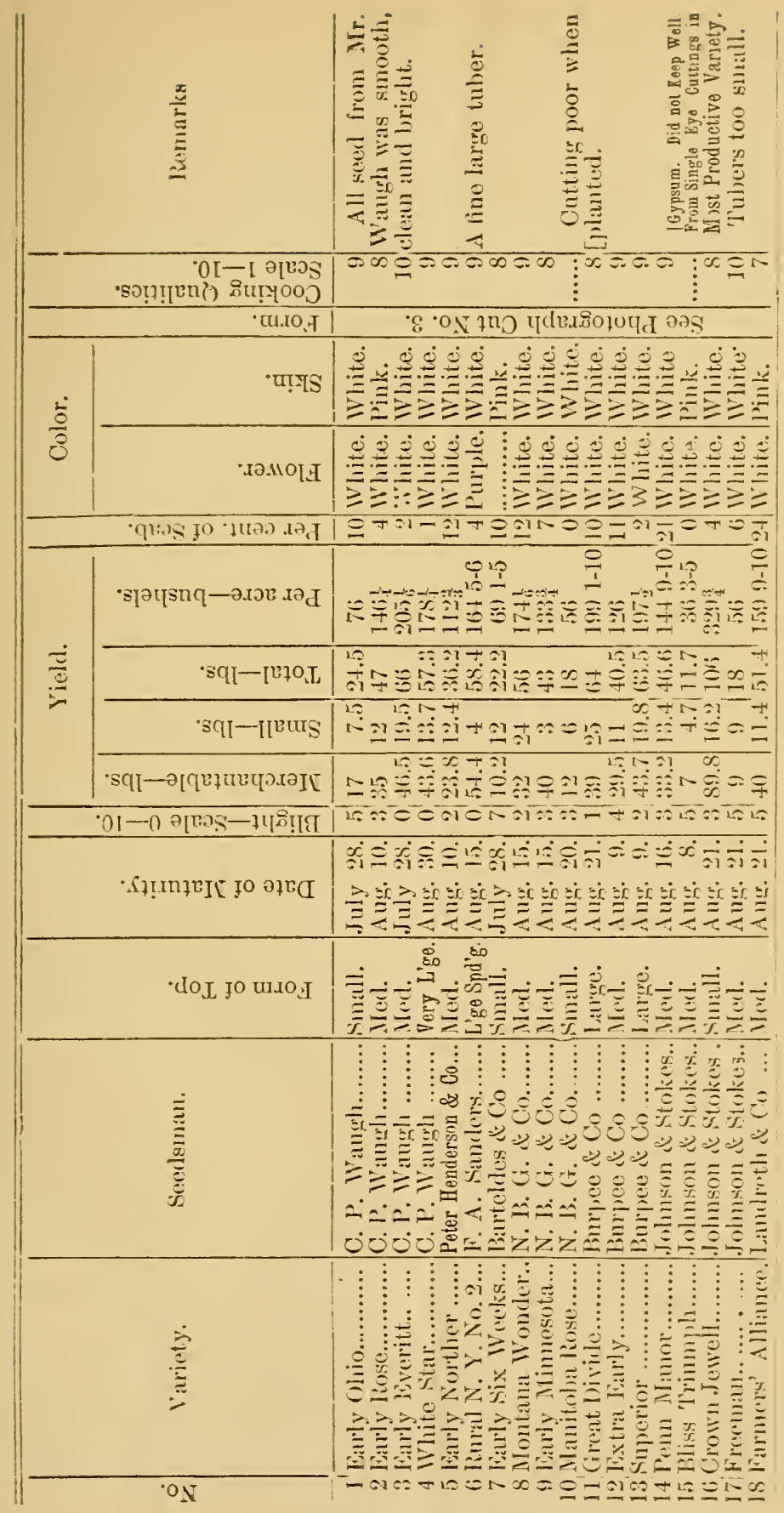


In column marked Cooking Qualities the scale is 1-10, 7 and below, poor, 8 fair, 9 good, 10 best.

In using the figures under the head of blight, 0 indicates that no blight was seen on that variety: and each number from that to ten represents the percentage of blight, the figure ten being the worst condition possible. As previously stated Nos. 8, 9, 10, 15, 16 and 17 were all received in single eje cuttings, put up in gypsum. Although this is a practicable way of sending the potatoes as far as mailing is concerned, nevertheless it is a question as to its practicability for securing the best yield. We can see that if the ground was ready when they were received, and the cuttings miade just before sending, no harm could result from this method: but when we are not sure of either condition there is chance for untrustworthy results. We mention this for the reason that we were troubled in this way when our cuttings were received. They probably were all right when sent, butgas we were obliged to keep them some time before the right time for planting, in some instances they were thought to have lost more or less vitality. It so happened that the variety giving the largest yield is one received in the single eye cutting form. We think this exceptional, however.

\section{Varieties Recommended.}

Those who study the tables can easily see the superiority of some of the varieties over others, but it may be desirable to give a list of those thought to have sufficient points for recommendation, as follows:

American Wonder, Rural New Yorker No. 2, Great Divide, Superior, Crown Jewell, Early Everitt, Maggy Murphy. We shall give these a further trial together with the following varieties; White Star, Early Norther, Montana Wonder, Farmer's Alliance, Badger Bell, Early Pinkese and Seedling No 99. These are not far behind the former in yield and may do fully as weil in future trials. Carman No. 1, (See Cut on front page) is a new introduction and we have a fine report from it elsewhere. We did not cultivate it extensively, only a few hills; however, it is worthy of trial by all on a small scale at least. From one medium potato we received 13 pounds this season. 


\section{The Leaf Blight of the Potato.}

The blight common to us in West Virginia and to the country in general, is caused by the fungus, Macrosporiurn solani. It attacks the potato croj during the latter part of May and is at its height either

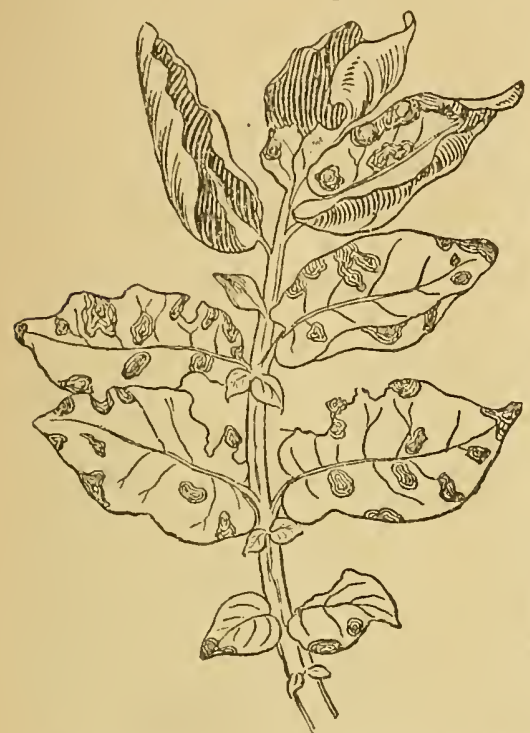
cluring June or the fore part of $\mathrm{Ju}$ ly, depending on the season. The early varieties suffer most. Its method of procedure is first to appear in very small dead spots in various places on the leaf, which at first are hardly perceptible when looking at the crop as a whole. These spots continue to enlarge and slowly merge together. It is at this advanced stage that the disease becomes moro noticeable; the leaf more often dies at the tips and edges first, having the appearance of being sunburned. The dead portion turns black, curls up and becomes very crisp, cracking off very easily when handled during dry weather. The accompanying cut, (Cut 4 ) is a fair representation of the disease, the lower leaflets characterizing the ear-

lier and the upper the more advanced stages of the disease. The loss is from the premature death of the vines; when the vines are killed of course the potatoes cease growing.

By examining the column marked blight in the tables on page 38 and 39 it will be seen that although these varieties were treated simiIarly, some few were able to withstand the disease by the aid of the Bordeaux mixture, while the remainder were affected in a greater or less degree. This, therefore, naturally leads us to conclude that some varieties are capable of resisting the blight to a greater degree than others. This may be the key to the success of such varieies as the Rural New Yorker No 2, American Wonder, Early Everitt and the (new) Carman No. 1. These are favorably spoken of everywhere. From experiments carried on the last two years, we feel safe in saying that some few varieties have become so susceptible to the blight that it is a question whether it is economy to use the Bordeaux mixture. The beneficial results in increased yield are not sufficient to pay for the time employed in spraying them. When such varieties behave thus, it is best to discard them for those that are benefitted by the expenditure of time and money. The greater majority of varieties are benefitted greatly by the spraying aud there is no doubt but that, speaking geuerally, it pays handsomely. The table shows the comparative resistance of each variety. In selecting a variety, therefore, if we can get a good yielder that can resist blinht, we approach nearer the desirahle potato. To be most successful the treatment must be at least three in number, beginning shortly before the 
disease makes its usual appearance, and continuing at intervals of two to three weeks, according to climatic conditions. It often bappens in some places that besides the common Colorado bettle, a very small black insect known as the flea beetle is very harmful to the leaves. If this is troublesome, it is kept in check by the addition of one pound of hard soap to eight gallons of the Bordeaux.

\section{Spraying Pumps.}

The kind of pump to be used depends upon the area of jour potato growing; if only a small patch is to be sprayed, the knapsack sprayer may answer the purpose. (See Cut 2, page 34). For a larger area or field an outfit similar to that of $\mathrm{Cu} ; 5$ is desirable. Besides using the

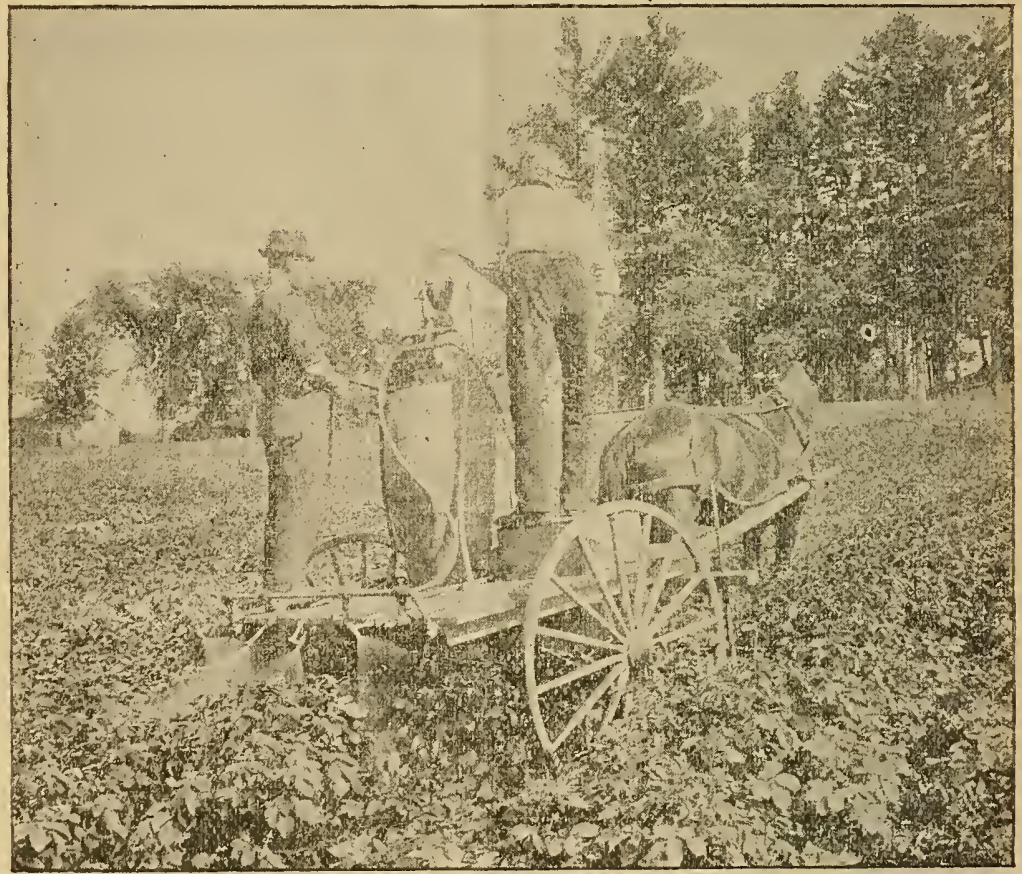

Cut כ.-SPRAYING OUTFit.

pump for this purpose by adjusting the nozzles it will serve to spray fruit trees, etc. By expending more or less energy at the handle a man can force a strong or light application at his will, and to almost any height. The wheels of the cart are six feet apart so as to cover two rows. The mixture is discharged through four spray nozzles at the rear of the cart, two over each row. The two nozzles are set at such an angle that they completely cover the foliage, one from the outer side in, and the other from the inner side out in each instance. A rod is so 
frsteved in front of the wheels that it brushes away the tops and keeps them from being run over. This arrangement is that of l'rof. L. $R$. Jones of the Vermont Agricultural Hixperiment Station and deserves recommendation. It is practicable, clieap and durable. Many inquiries have come to the Station in regard to spraying pumps; in every instance I artvise farmers to purchase a pump similar to the one last mentioned. If it is put on a barrel, they hare a machine that will cficiently spray large or small fruit trees, potatoes, vineyards, etc. It is a mistake to purchase a small pump, as poor results generally follow, the reason being that the work cannot he effectively done and it takes too much time. We believe the reason that more spraying is not done is because a number of our people have purchased small machines and they find they are not what they are resommended to be. Place the money in a good pump, that is the most importart thing. You want a pump with plenty of force. The knapsack sprayers are good for bushes and small areas, but will nct fil the place of a good force pump.

The following firms manufacture spray pnmps: also furnish catalogue on application:Fiteld Force Pump Co., Goulds Mfg. Co, P. U. Lewis Mfg. Co., Wm. Boekel \& Co.,

The Deming Co., Jockport, N. X. Sencea Fills, N. Y. Catskill, N. Y.

No. 518 Vine St., Philadelphia, Pa.

Nizon Nozzle and Jlachime Co., Dayton, Uhio. Wm. Stahl, W. \& B. Douglas,

Dayton, Uhio.

Quiney, lil.

Middletown, Conn.

\section{Potato Scab.}

This disease is so conımon that no particular explanation is necessary. The photograph, (Cut 6) presents some of the worst characteristic forms, It has been found through experimentation that by soak- 


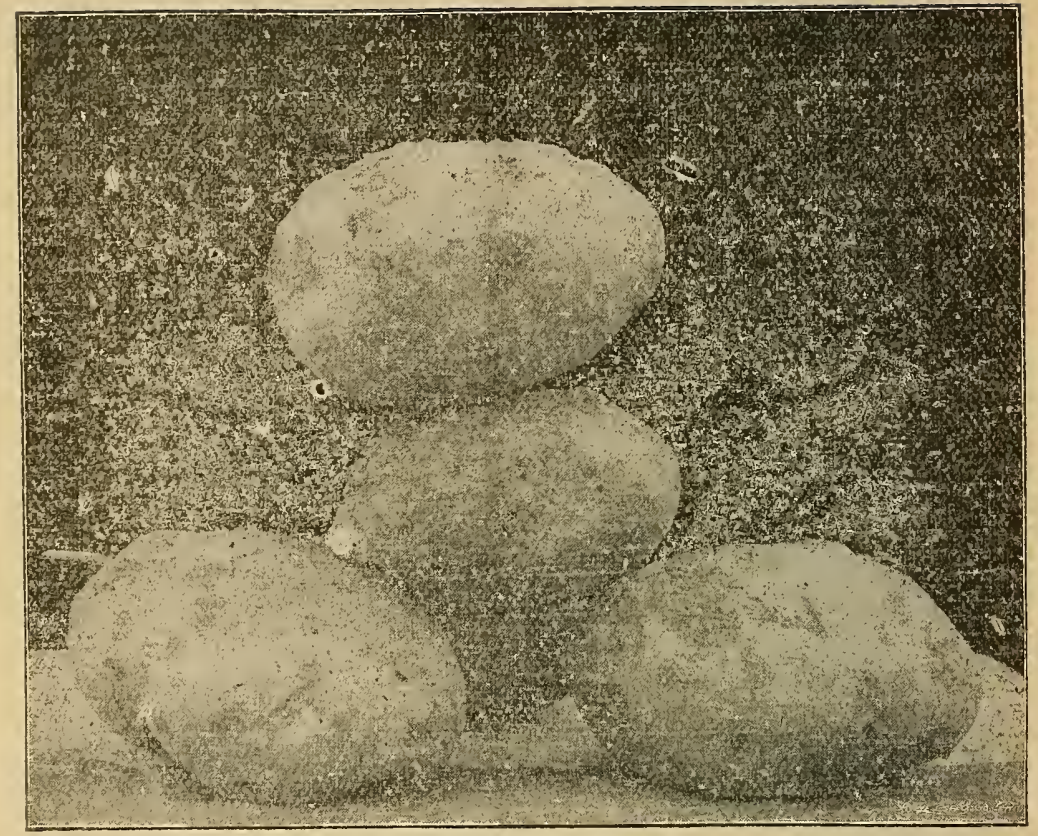

CUT 6.-TORST FORMS OF SCAB.

ing the seed potatoes in a solution of corrosive sullimate (Poison) the scab was eliminated. Since this discovery, it has been tried by various experimenters and practical potato-growers and pronounced a success. The treatment now used is two ounces of corrosive sublimate (bichloride of mercury) to sixteen gallons of water. It is more readily dissolved by using a few gallons of hot water at first and then diluting to the righi, number (16). Never use metal dishes as it corrodes them; use only wooden pails, earthen er glass ware.

For treating large or small quantities select, therefore, a vessel accordingly. For a large quantity a hogshead, barrel or a large tub could be employed; and for a small quantity a half barrel, small tub or good-sized wooden pail. A convenient way to immerse the tubers is to place them in a coarse sack; after they have remained in the solution for one and a half hours, they are removed and when cut are ready for planting.

The treatment is very simple, comparatively inexpensive, (the cor- 
rosive sublimate ensts about $\$ 1.00$ per pound or about two oz. for $15 \mathrm{c}$ )

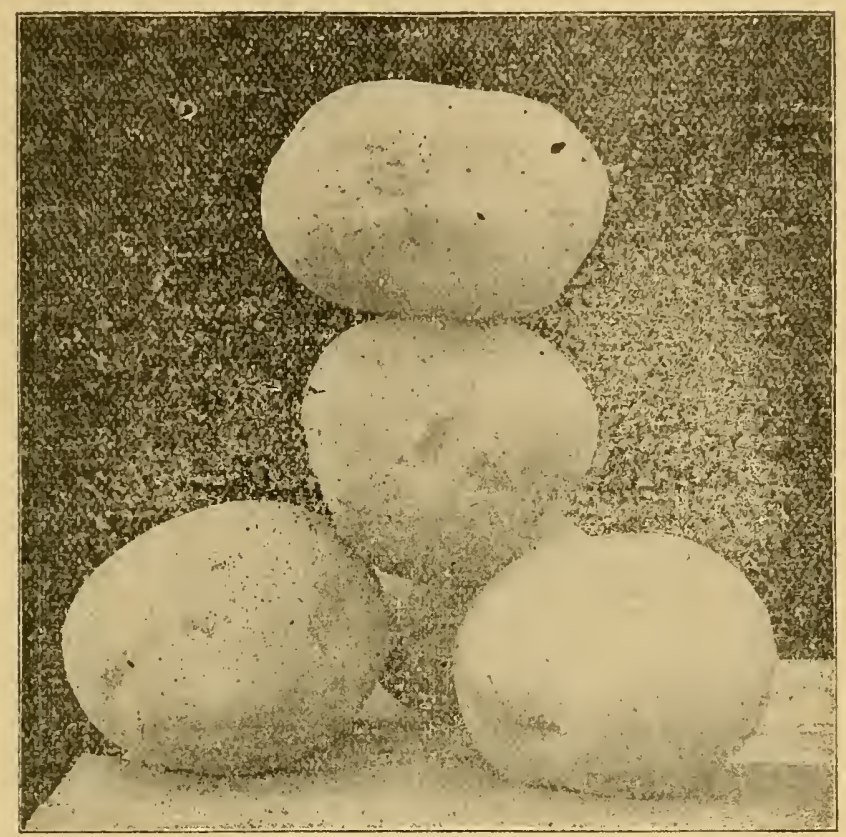

Cot 7. - The Crop from Treated Seed.

and is worthy of a trisl. The corrosive sublimate is very poisonous; therefore be cautious. The vessels can be used again if thoroughly cleansed with clean waler and again with a little sal-soda in water. This remedy is reported as used by hundreds of our farmers in the past and in no instance have unfavorable reports been received. When the treatment costs approximately 1 wo cents per bushel, and the benefits obtained are so marked, it appears that no potato-grower can afferd to ignore the remedy.

Cuts 7 and 8 are examples of treated and untreated potatoes respectively. The seed potatoes used were similar to those seen in Cut 6 .

\section{Scab Experiments.}

An experiment was inaugurated toward finding out, if possible, 
the effect of lime and manure, which, if in the soil, is thought by many to

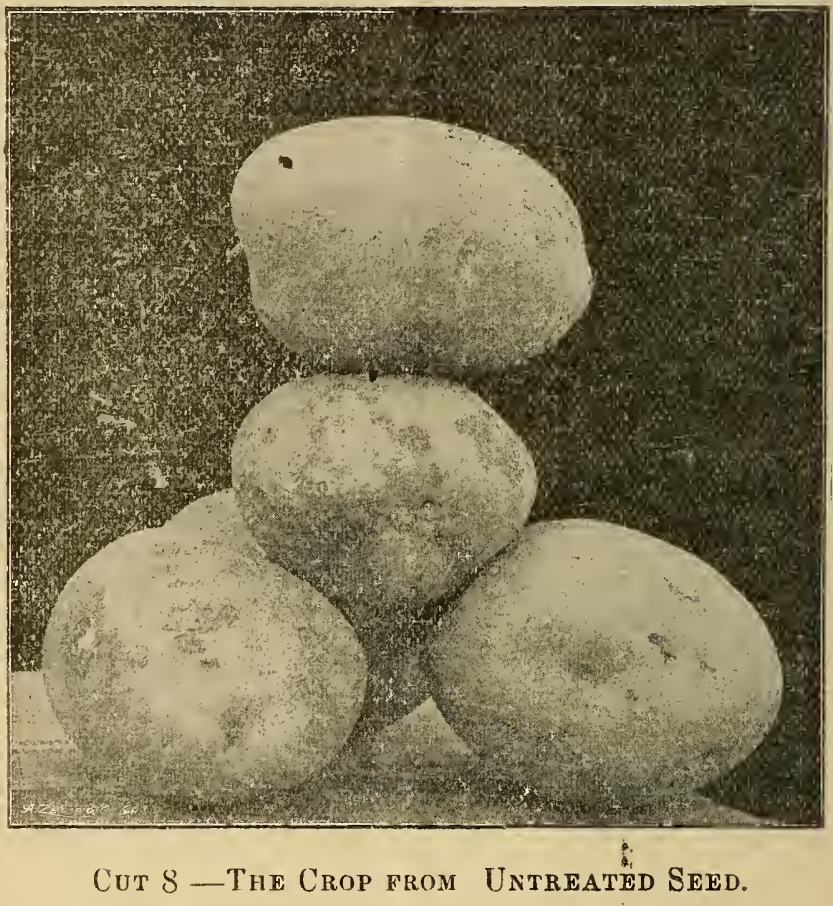

aggravate the scab disease. Two good sized plots, each 75 feet long and 28 feet wide were measured off for the experiment. Both were in every respect similar ; therefore each was used as a check on the other. 'They were divided up into eight rows, each 75 feet long and $3 \frac{1}{2}$ feet apart. Each row was treated as follows: After throwing out the furrow for planting, row 1 was given a thorough dressing with barnyard manure ; row 2 a very thorough dressing of lime ; row 3 , a dressing of both ( $L$ \& $M$, mixed togeller, while in row 4 nothing was used. Rows $5,6,7$ and 8 were given the same teatment as $1,2,3$ and 4 , respectively. Rows $1,2,3$ and 4 were plunted with potatoes unsoaked and rows $b, 6$, 7 and 8 with those soaked in the ordinary solution of corrosive sublimate. $r_{i}$ he following plan indicates it more clearly for each plot.

Row 1. Manure-Potatoes.

"2. Lime + Potatoes.

"3. Manure+lime+Potatoes.

"4. Nothing + Potatoes.

“5. Manure+soaked potatoes.

"6. Lime+soaked potatoes.

“7. Manure+Lime-soaked potatoes,

"8. Nothing + soaked potatoes. 
The potatoes were not planted until June 5th. The summer being a dry one, they did not do well, but tise conditions being simlat in every instance, we give the following tabulated result as they were taken after cligging on October $6 \mathrm{~h}$.

In the columu marked Fertilizer, $\mathrm{M}=$ Ianure, $\mathrm{L}=$ Lime, $\mathrm{O}=$ nothing.

\section{PLCOT I.}

\begin{tabular}{|c|c|c|c|c|c|}
\hline Row. & Fertilizer. & $\mid \begin{array}{c}\text { soaked } \\
\text { or } \\
\text { C'n-soaked }\end{array}$ & $\begin{array}{l}\text { Yield } \\
\text { Poumds. }\end{array}$ & $\begin{array}{l}\text { Per Cent } \\
\text { of Scab. }\end{array}$ & Remarks. \\
\hline $\begin{array}{l}1 \\
2 \\
3 \\
4 \\
5 \\
6 \\
7 \\
8\end{array}$ & $\begin{array}{l}\text { M. } \\
\text { L. } \\
\text { M. \& L. } \\
\text { O. } \\
\text { MI. } \\
\text { L. } \\
\text { M. \& L } \\
\text { O. }\end{array}$ & $\begin{array}{c}\text { Un-soaked } \\
\text { ", } \\
\text { " } \\
\text { Soaked. } \\
\text { " } \\
\text { " }\end{array}$ & $\begin{array}{c}8.6 \\
12.4 \\
11.4 \\
20.2 \\
20 . \\
18.4 \\
18 . \\
8 .\end{array}$ & $\begin{array}{c}8 \\
-43 \\
-4 \frac{1}{1} \\
2 \frac{1}{2} \\
9-10 \\
8 \frac{1}{3} \\
1 \frac{1}{2} \\
2 . \\
4 \frac{3}{4}\end{array}$ & \\
\hline
\end{tabular}

PLOT II.

\begin{tabular}{|c|c|c|c|c|c|}
\hline Row. & Fertilizer. & $\begin{array}{l}\text { Soaked or } \\
\text { Un-soaked }\end{array} \mid$ & $\begin{array}{l}\text { Yield } \\
\text { Ponnds. }\end{array}$ & $\begin{array}{l}\text { Per Cent } \\
\text { of Scab. }\end{array}$ & Remarks. \\
\hline $\begin{array}{l}1 \\
2 \\
3 \\
4 \\
5 \\
6 \\
7 \\
8\end{array}$ & $\begin{array}{l}\text { M. } \\
\text { I. } \\
\text { M. \& L. } \\
\text { O. } \\
\text { M. } \\
\text { L. } \\
\text { M. \& L. } \\
\text { O. }\end{array}$ & $\mid \begin{array}{c}\text { Un-soaked } \\
\text { "، } \\
\text { "w } \\
\text { Soaked. } \\
\text { " } \\
\text { " }\end{array}$ & $\begin{array}{l}14 . \\
27.4 \\
25 \\
15 \\
18 \\
17 \\
26 \\
11\end{array}$ & $\begin{array}{ll}3 & 3-5 \\
5 & 1-7 \\
4 & 3-4 \\
2 & 4-5 \\
3 \\
1 \\
21 \\
2 \frac{1}{7} \\
9-70\end{array}$ & \\
\hline
\end{tabular}

By examining these tables it can be easily seen that in every in. stance with but one exception, the scab was rorse on the unsoaked potatoes. The one instance was the row of lightest yield, and therefore the results are not as reliable as the otherz. In order to show the com. parative percentage of scab with the untrated potatoss when tested with these fertilizers, a third table is made from the two former, bringing these results out more clearly.

By taking the average of rows 1, 2, 3 and 4 from each plot, we secure their respective scab producing qualities. 
Comparative Effect of Lime and Manure on Scab.

\begin{tabular}{|c|c|c|c|c|c|}
\hline Row. & FERTI'Z'R. & $\mid \begin{array}{c}\text { SOAKED } \\
\text { OR } \\
\text { UN-So'K'D. }\end{array}$ & $\begin{array}{l}\text { Average } \\
\text { Yieid } \\
\text { Pounds. }\end{array}$ & $\begin{array}{c}\text { Average } \\
\text { Per Cent } \\
\text { Scab. }\end{array}$ & REMARKS. \\
\hline $\begin{array}{l}1 \\
2 \\
3 \\
4\end{array}$ & $\begin{array}{l}\text { M. } \\
\text { I. } \\
\text { M. \& L. } \\
\text { O. }\end{array}$ & $\begin{array}{c}\text { Un-So'k'd. } \\
\text { "، } \\
\text { " }\end{array}$ & $\begin{array}{l}11.3 \\
19.9 \\
18.2 \\
17.6 \\
\end{array}$ & $\begin{array}{ll}5 & 4-5 \\
4 & 9-10 \\
3 & 5-8 \\
1 & 1-3 \\
\end{array}$ & $\begin{array}{l}\text { Most Scab. } \\
\text { Least Scab. }\end{array}$ \\
\hline
\end{tabular}

From this table, therefore, and as far as one year's experimentation can be depended upon, we conclude that manure by itself greatly assists in producing scabby potatoes. Lime comes next to manure, not quite as bad. Lime and manure when mixed are not as bad as either by itself. Where either was used, the comparative results were as follows: Where manure was used, the scab was practically five times as bad as where nothing was used; with lime, it was four times as bad; where manure and lime were used together, it was three times as bad.

We intend repeating this experiment another year, and mention it here that others may be induced to try it and report. The fact, if further established, will point out the still greater inıportance of soaking the potato seed in the corrosive sublimate solution when manure or lime is present.

\section{Reports From Practical Potato-Growers In West Vir- ginia.}

From reports received from our potato-growers throughout the State, we have selected two which are of a general nature and which we trust will be appreciated by our farmers. They are as follows:

Wellsburg, West Vtrginia, \}

Prov. F. IV. Rane, November $13,1894$.

Morgantown, West Virginia.

My Dear Sir:-I am delighted with the cut of your potatoes. It has been a tough year on potatoes. I am anxious to see your report, so please send it as soon as issued.

Your Early Ohio seems to be true to name, but the Early Rose looks more like an Ohio than a lrose to me.

The Early Rose and Everitt are so much alike that it is impossible to tell one from the other, only that they do not ripen at the same time; the Everitt being from one to two weeks later.

The Early Everitt, White Star, Rural New Yorker No. 2, American Wonder and Superior, are very much the same as I grow them.

The White Star is specked and soggy with me and I shall not plant it again, although it is one of the finest croppers I have. How is it with you?

The Freeman seems to grow with you like it does with everybody else, small.

Is your No. 12 Burpee's Extra Early? If so it is very different fron. what I received from Burpee; in fact my seed did not prove to be early or any account whatever. I think your Nos. 30 and 33 the same.

My method of culture can be told in very few words: 
Never plant until the soil is ready. What I mean by this is, plow the ground when it will crumble thoroughly, pulverize as deen as plowed, and plant potatoes als deep als soil will perinit. Keep a few inches of the soil on top crerlastingly stirred up. Kill all bugs (Colorado beetles), and the potatocs will slo the rest.

As to fertilizers, I have been experimenting in a small way with complete potato and other fertilizers, but an not ready to report definite results.

I have a few motes on different varieties of potatoes taken on Aug. 10 and at digging time, which I enclose.

lours Truly,

C. P. W 


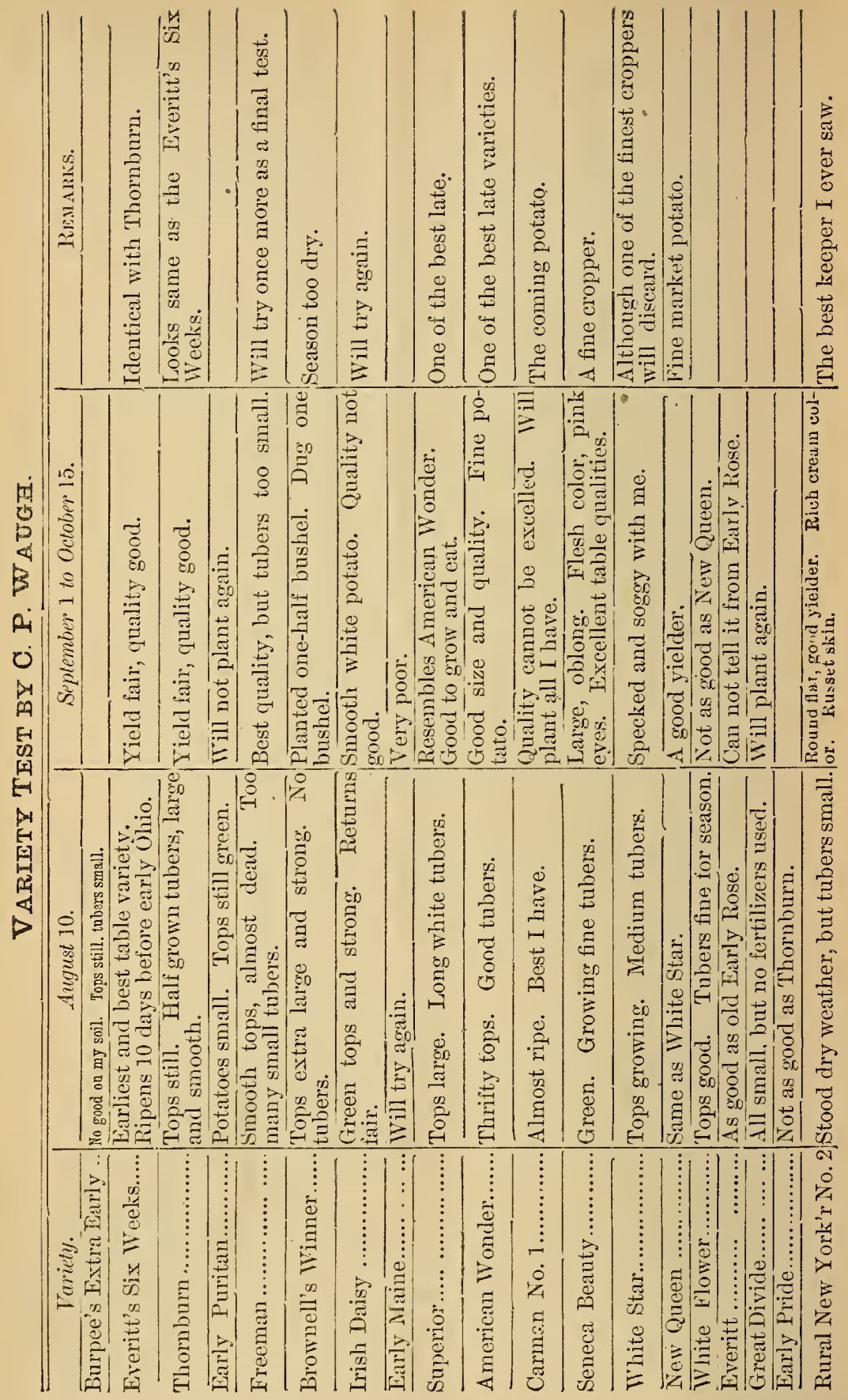


Prof. F. Wy. Raxe,

Morgantown, Wv. Vá.

De.IR Sir:--Your letter at hand, asking me for some potato talk. Wrell, pread may be the staff" of life, but potatoes are certainly the staff upon which the farmer ean put his dependence to lift the wortgage from his farm, tariff or no tariff.

\section{Time to Plant.}

Not until the ground can be handled safely and put into first-class condition. Lay all other work aside when that hour comes; giving them every adrantage during the carly growing seasou; and secure all the top growth before the hot June suns come upon them.

\section{Cullure.}

Start the harrow early-you can't start too early after the seed is in the ground; ospecially after every rain and until the tops are well up. Then start the tools into the ground, narrow blarles not over 1 inches, going as deep as your cround was plowed (if nothing prevents) and as close to the plants as is possible. 'There is no danger' of disturbing the roots at that time. Know where the roots are all the time, let there be no guess work. Never say you have laid your potatoes by until they are either on the market or in the cellar.

\section{Condition.}

Let there be no mistake about the condition of the soil as to fertility; make crery point right and if failure follows. it will be due to some cause you had no controlover, while you lessen your chances for failure and secure better crops in consequence.

\section{Seed.}

The seed should be sound, well or thoroughly developed, and not weakcned by sprouting in the cellar or pits. These are important points.

i'here is such a vast number of varieties it is almost impossible for any one person to select other than for themselves. Take the kinds your market demands. The market makes the distinction and we are obliged to fall into line.

It costs but a trifle to test a few varieties every year, and by carefully observing every point, as to habits, viz: Setting tubers; withstanding blight, bugs, hot suns; setting more tubers than can be carried to completion; table qualities, etc. Every nne can he suiterl. The table qualities must not be forgotten, for that is the last and final trial which they must stand, or forcver be concemned. Yours very respectfully,

Wellsburg, W. VA., Nov. 19, 1894.

JNo. W. SANDERS.

\section{Donations to Horticultural Department.}

J. A. Everitt, six varieties potatoes.

C. P. Wangh, four varieties potatoes, one peck each.

J MI. MIG Gowen, one McGoreu Spray ing Nozzle.

Jas. M. Thornburn, Carman No 1, Potato.

P. C. Lewis, M'f'g Co, Lewis' Instantaneous Spray Nozzle.

Peter Henderson \& Co., Early Norther Potato.

F. A. Sanders, Rural New Yorker No. 2, Potalo.

Jas. A. Blanchard, 1 gal. can Bordeaux Mixture. 
Acknowledgments.

Cuits Nos. 6, 7 and 8, from Prof. L. R. Taft of the Michigan Agricultural College.

Cuts Nos. 4 and 5, from Prof. L. R. Jones of the Vermont Agricultural Experiment Station.

\section{Summary Remarks.}

I. This bulletin is published in the interest of all PotatoGrowers, giving varieties best adapted to our State; methods of combating clisease and insects, culture, etc.

II. The photograph Cut 3 page 33 and the small cut of the Carman No. 1 on front page give the characteristic form of the potato as grown here at the Experiment Station. Its name may be found by referring to the number upon it.

III. Try the Bordeaux mixture next year for the blight. Leave a few rews unsprayed in order to see if it pays. Add Paris green to the mixture for the Colorado Potato Beetle in the same proportion as if the mixture were water. See page 34.

IV. Single eye cuttings as seut out by seedsmen in gypsum are to be purchased with caution. If cut some time before shipped, or if kept some time after receiving until favorable conditions for planting, they are liable to lose more or less vitality.

V. The preferable varieties in our test are the American Woncer, Rural New Yorker. No. 2, Great Divide, Superior, Crown Jewell, Early Everitt, Miggy Murphy and possibly the (new potato) Carman No. 1.

VI. Some varieties appear to be capable of resisting blight to. a greater degree than others. This may be the key to the success of such varieties as American Wonder, Rural New Yorker No. 2, etc. See page 39.

VII. Use spraying pumps that will do the work satisfactorily. Small cheap affairs are worse than none at all. See page 40.

VII. Try soaking jour seed potatoes in corrosive sublimate mixture and thereby lessen your scabby potatoes. page 41 .

Try some soaked and some unsoaker; it will convince jou. See'

IX. From a single experiment carried on during the past jear, the results showed that where barn-yard manure was used alone the potatoes were five times as scablyy as they were where nothing was used. Where lime was used alone, they were four times as bad. Where both manure and lime were used together the scab was three times as bad. See page 44.

$X$. Should IX be further established by future experiments, it will point out the still greater importance of soaking the potato seed in corrosive sublimate when manure of lime is present.

XI. A limited amount of the varieties named in the tables, (pages 36 and 37) will be sent to residents of the State for test purposes, provided they assure us of a report and send us stamps for postage, at the rate of $2 \mathrm{oz}$. for one cent, the regular postage rate.

F. Wir. Rane. 



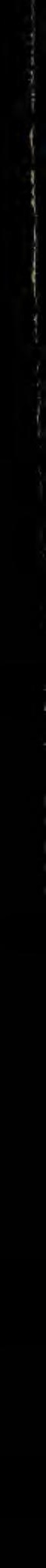


